\title{
Effects of Red and Fermented Ginseng and Ginsenosides on Allergic Disorders
}

\author{
Myung Joo Han ${ }^{1}$ and Dong-Hyun Kim ${ }^{2, *}$ \\ 1 Department of Food and Nutrition, Kyung Hee University, Seoul 02447, Korea; mjhan@khu.ac.kr \\ 2 Neurobiota Research Center, Department of Pharmacy, Kyung Hee University, Seoul 02447, Korea \\ * Correspondence: dhkim@khu.ac.kr; Tel.: +82-2-961-0374
}

Received: 21 February 2020; Accepted: 15 April 2020; Published: 20 April 2020

\begin{abstract}
Both white ginseng (WG, dried root of Panax sp.) and red ginseng (RG, steamed and dried root of Panax sp.) are reported to exhibit a variety of pharmacological effects such as anticancer, antidiabetic, and neuroprotective activities. These ginsengs contain hydrophilic sugar-conjugated ginsenosides and polysaccharides as the bioactive constituents. When taken orally, their hydrophilic constituents are metabolized into hydrophobic ginsenosides compound K, Rh1, and Rh2 that are absorbable into the blood. These metabolites exhibit the pharmacological effects more strongly than hydrophilic parental constituents. To enforce these metabolites, fermented WG and RG are developed. Moreover, natural products including ginseng are frequently used for the treatment of allergic disorders. Therefore, this review introduces the current knowledge related to the effectiveness of ginseng on allergic disorders including asthma, allergic rhinitis, atopic dermatitis, and pruritus. We discuss how ginseng, its constituents, and its metabolites regulate allergy-related immune responses. We also describe how ginseng controls allergic disorders.
\end{abstract}

Keywords: Panax sp.; ginsenosides; polysaccharides; allergy; immune system

\section{Introduction}

Allergies including asthma, allergic rhinitis, atopic dermatitis (AD), atopic conjunctivitis, and anaphylaxis are common, persistent, and incorrigible disorders [1,2]. The prevalence of allergies ranges from $10 \%$ to $40 \%$ of the population worldwide [2]. A variety of drugs, including immune modulators and biological agents, have been developed for the treatment of allergies [3,4]. However, they have certain limitations due to their side effects: glucocorticoids often induce the adrenal insufficiency and cause infections and skin atrophy; calcineurin inhibitors cause neurotoxicity, nephrotoxicity, infections, and skin cancers; and biological agents such as omalizumab increase infections and tumor development $[5,6]$. Therefore, natural products with fewer adverse effects such as red ginseng and radix glycyrrhizae have been frequently used as the functional foods and traditional Chinese medicines [7,8]. Many studies have been conducted on their anti-allergic effects. Of these, we focused on the anti-allergic effects of ginseng and the constituent ginsenosides and polysaccharides in the present review.

\section{Chemistry of Ginseng}

The term ginseng is used to represent the dried root of the Panax spp. (family Araliaceae), including Panax ginseng Meyer (Korean ginseng), Panax quiquifolium L. (American Ginseng), and Panax notoginseng (Burk.) FHChen (notoginseng) $[9,10]$. When the fresh roots of these Panax spp., particularly Korean ginseng, are dried or steamed/dried, they are named white ginseng (WG) or red ginseng (RG), respectively. Ginseng has been used world-wide as herbal medicine or functional food for promoting vitality, increasing the resistance to stress, and modulating 
immune responses [11,12]. The bioactive constituents are considered to be ginsenosides, such as protopanxadiol-type, protopanaxatriol-type, and oleanane-type ginsenosides, and polysaccharides such as ginsan [13] (Figure 1). Of protopanaxadiol-type ginsenosides, ginsenosides Rb1, Rb2, Rc, Rd, and $\operatorname{Rg} 3$ and quinquenosides I and II are highly isolated from ginseng [14,15]. Of protopanaxatriol-type ginsenosides, ginsenosides Rg1 and Re are frequently isolated [16,17]. Of oleanane-type ginsenosides, ginsenoside Ro and chikusetsusaponin are isolated [10,18,19].

\begin{tabular}{|c|c|c|c|c|c|}
\hline & Ginsenoside & $M$ & R1 & $\mathbf{R} 2$ & R3 \\
\hline & Ginsenoside Rb1 & A & Glc-Glc- & GIc-GIc- & H \\
\hline $\mathbf{A}$ & Ginsenoside Rb2 & A & GIc-GIc- & $\operatorname{Ara}(p)-G l c-$ & H \\
\hline & Ginsenoside Rc & A & Glc-GIc- & Ara(f)-GIc- & H \\
\hline & Ginsenoside Rd & A & Glc-GIc- & GIc- & H \\
\hline & Ginsenoside Rg3 & A & Glc-GIc- & H & H \\
\hline & Ginsenoside Rg5 & B & Glc-Glc- & H & H \\
\hline & Ginsenoside F2 & A & Glc- & Glc- & H \\
\hline & Ginsenoside Rh2 & A & Glc- & H & H \\
\hline & Compound K & A & H & Glc- & H \\
\hline & Protopanaxdiol & A & H & $\mathrm{H}$ & H \\
\hline & Ginsenoside Re & A & H & Glc- & Rha- Glc-O- \\
\hline & Ginsenoside Rf & A & H & H & GIc-GIc-O- \\
\hline & Ginsenoside Rg1 & A & H & Glc- & Glc-O- \\
\hline & Ginsenoside Rg2 & A & H & H & Rha- Glc-O- \\
\hline & Ginsenoside Rh1 & A & H & H & GIc-O- \\
\hline & Ginsenoside F1 & A & H & Glc- & $\mathrm{OH}$ \\
\hline & protopanaxatriol & A & H & H & $\mathrm{OH}$ \\
\hline
\end{tabular}

Figure 1. The Representative Ginsenosides Contained in WG and RG.

\section{The Role of Gut-Microbiota-Mediated Metabolism in the Mediation of Biological Effects of Ginseng}

Korean ginseng, American ginseng, and notoginseng all contain hydrophilic sugar-conjugated ginsenosides and polysaccharides as the bioactive components [13]. Of ginsenosides, hydrophilic ginsenosides $\mathrm{Rb} 1, \mathrm{Rb} 2, \mathrm{Rc}$, and Re have a variety of pharmacological activities such as anti-inflammatory, antidiabetic, hepatoprotective, and anticancer activities in the in vivo studies [13,20]. However, when these ginsenosides or ginseng extracts are orally gavaged, these ginsenosides such as $\mathrm{Rb} 1$ and Re are not easily absorbed into the blood [21,22] (Figure 2). Therefore, these contact with gut microbiota, which transform hydrophobic metabolites such as compound $\mathrm{K}(\mathrm{CK})$ and ginsenoside Rh1. These metabolites such as CK are detected in the blood rather than parental constituents [21,22]. In addition, when ginsenoside Rb1 was orally administered in germ-free rats, $\mathrm{Rb} 1$ and $\mathrm{CK}$ both were not detected in the blood [23]. To understand the reason for this, when ginsenosides were incubated with fecal bacteria, they were strongly and quickly transformed into CK [24]. Orally administrated ginsenoside Rb1, a main constituent of Panax ginseng, is transformed to CK through ginsenosides $\mathrm{Rd}$ and F2 in humans and animals by gut bacteria, such as Bifidobacterium sp. and Bacteroides sp., and thereafter these metabolites are detected in the blood and urine [25-27]. The absorption of gut-microbiota-mediated metabolites from ginseng constituent ginsenosides are significantly affected by intestinal environmental factors such as diets and antibiotics [28-31]. The biological activities of ginsenosides $\mathrm{Rb} 1$ and Re, such as anti-inflammatory and anti-allergic activities, are attenuated in mice by oral gavage of antibiotics [30,31]. When RG extract is orally administered in humans and mice, ginsenoside $\mathrm{Rd}$ is the most highly detected, followed by ginsenoside Rg3, ginsenoside 
Rg1, and protopanaxatriol [32,33]. However, when bifidobacteria-fermented red ginseng (fRG) is orally administered, ginsenoside Rd is the most highly detected, followed by ginsenoside Rg1, CK, ginsenoside Rg3, and protopanaxtriol [32,33]. The contents of these ginsenosides except ginsenoside Rg3 absorbed into the blood are significantly higher in the fRG-treated volunteers and mice than in the RG-treated volunteers and mice. However, when notoginseng extract, whose which main constituents are ginsenosides $\mathrm{Ra} 3, \mathrm{Rb} 1, \mathrm{Rd}, \mathrm{Re}$, and $\mathrm{Rg} 1$ and notoginsenoside $\mathrm{R} 1$, is orally administered to rats, the compounds mainly absorbed to the blood are ginsenosides Ra2, Rb1, and Rd, including CK [34]. This is controversial. Nevertheless, of parental ginsenosides and their metabolites, CK, ginsenosides $\mathrm{Rh} 1, \mathrm{Rh} 2$ and protopanaxatriol, which are hydrophobic metabolites of ginsenosides by gut microbiota, exhibit the most potent biological effects compared to those of parental compounds [31-33,35-40]. These results suggest that when ginseng extracts are orally administered, their hydrophilic constituents are metabolized by gut microbiota and their metabolites absorbable into the blood can express pharmacological effects: the pharmacological activities of ginseng extracts may be dependent on the absorbable metabolites produced by gut microbiota.
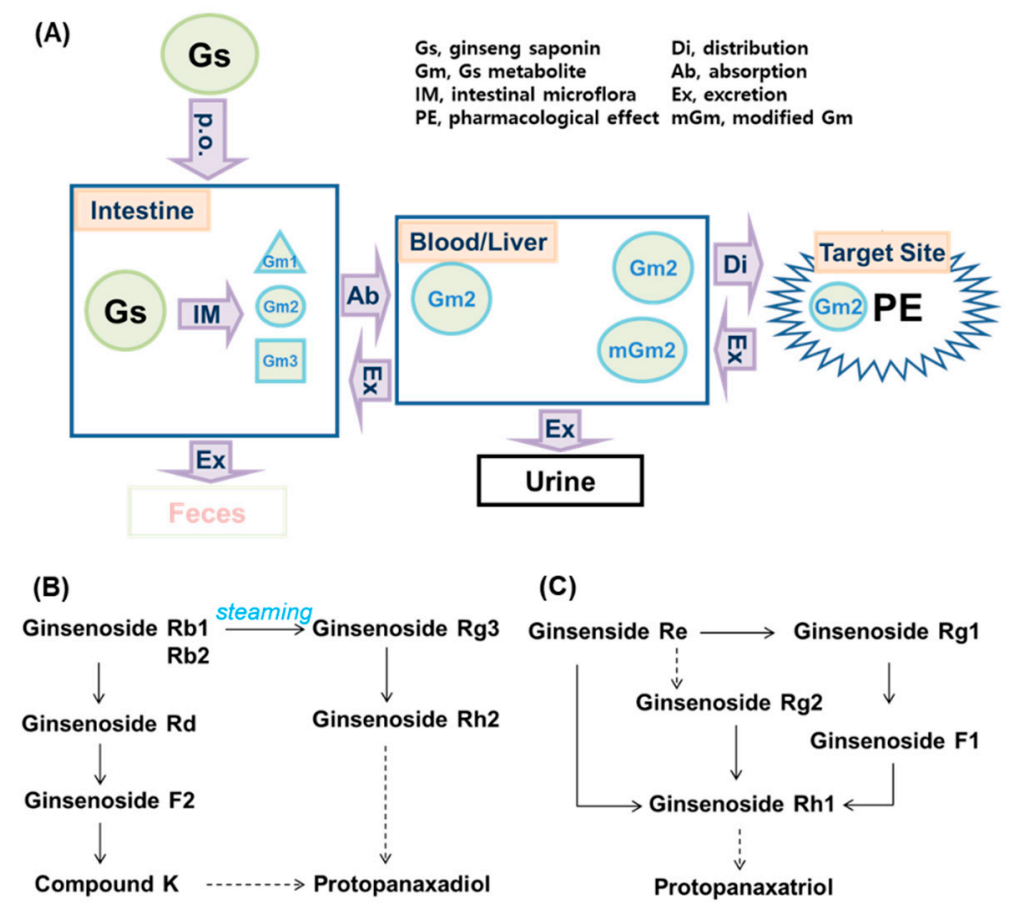

(C)

Figure 2. The proposed metabolic pathway of ginseng and its constituent ginsenosides by gut microbiota. (A) The fate of orally administered ginseng saponins in vivo. (B) The metabolic pathway of protopanaxadiol-type ginsenosides. (C) The metabolic pathway of protopanaxatriol-type ginsenosides. Solid arrows, potently proceeded; dashed arrows, weakly proceeded.

\section{Anti-Allergic Effects of Ginseng}

Ginseng extracts including RG extracts have been used in the traditional Chinese medicine for the treatment of allergic diseases including asthma, rhinitis, and $\mathrm{AD}[7,8,41]$. Actually, many studies have been performed to support their anti-allergic effects in vitro, in animals, and in patients with allergic disorders.

\subsection{The In Vitro and In Vivo Anti-Allergic Effects of Ginseng}

The anti-allergic effects of ginseng have been mainly studied in vitro, in animals, and in patients with allergic disorders (Table 1). First, Kim and Yang evaluated the effects of WG on ovalbumin-induced asthma in mice [42]. They found that intraperitoneally injected RG restored the ovalbumin-induced expression of eosinophil major basic protein (EMBP), interleukin (IL)-1 $\beta$, IL-4, IL-5, 
and tumor necrosis factor (TNF)- $\alpha$ expression in lung tissues. RG inhibited the ovalbumin-induced numbers of goblet cells and mitogen-activated protein kinases (MAPKs) in the bronchoalveolar lavage fluid of mice. Babayigit et al. reported that orally administered RG extract suppressed the chronic airway inflammation and mast cell populations in ovalbumin-sensitized mice [43]. Oral administration of WG or RG alleviated IL-4, IL-5, and IL-13 expression and immune cell infiltration in the bronchoalveolar regions of mice with ovalbumin-induced asthma [44]. They also suppressed IgE levels. Of these, RG more strongly lowered IgE level. Lee et al. reported that RG and fRG reduced serum IgE and ovalbumin-specific IgE levels and intestinal mucosal mast cell protease (MMCP)-1, IL-4, TNF- $\alpha$, cyclooxygenase (COX)-2, and inducible NO synthase (iNOS) expression in ovalbumin-sensitized mice [45]. Furthermore, RG and fRG inhibited IL-4 expression in phorbol 12-myristate-13-acetate/A23187-stimulated RBL-2H3 cells and alleviated ovalbumin-induced allergic rhinitis in mice [46]. In particular, fRG potently reduced nasal allergy symptoms; IgE level in the blood; IL-4 and IL-5 levels in nasal mucosa; and mast cell, eosinophil, and Th2 cell populations in bronchoalveolar lavage fluid and restored ovalbumin-induced gut dysbiosis. The inhibitory effects of fRG in the treatment of allergic rhinitis were better than those of RG. Jung et al. reported that RG suppressed IL-4 and IL-5 levels and eosinophil populations in the nasal lavage fluid of ovalbumin-sensitized mice [47]. RG increased ovalbumin-suppressed splenic IL-12 expression; IFN- $\gamma$-to-IL-4 ratio; and small intestinal CD8-, IFN $\gamma_{-}^{-}$, and IgA-positive cell populations in ovalbumin-sensitized mice [48]. Furthermore, fRG treatment improved the activities and emotions of quality of life. These results suggest that RG and fRG can alleviate allergic rhinitis in mice by suppressing IgE, IL-4, IL-5, and IL-13 expression and restoring altered gut microbiota and that fRG may display anti-allergic rhinitis activity more strongly than RG did due to the richness of absorbable ginsenosides.

Table 1. Summary of ginseng extract effects on allergic disorders.

\begin{tabular}{|c|c|c|c|}
\hline Ginseng & Effect & Dosage/Ad. Route & Ref \\
\hline \multirow{4}{*}{ RG } & $\begin{array}{l}\text { in mice with OVA-sensitized asthma/rhinitis } \\
\text { - Suppressed IgE, MMCP-1, IL-1 } \beta \text {, IL-4, IL-5, } \\
\text { IL-13, TNF- } \alpha, \text { COX-2, and iNOS expression; } \\
\text { MMPK and NF- } \mathrm{B} \text { activation; and mast cell, } \\
\text { eosinophil, and Th2 cell populations } \\
\text { Increased ovalbumin-suppressed splenic IL-12 } \\
\text { expression; IFN- } \gamma \text {-to-IL-4 ratio; and small } \\
\text { intestinal CD8-, IFN } \gamma-\text {, and IgA-positive } \\
\text { cell populations } \\
\text { - Alleviated chronic airway inflammation, nasal } \\
\text { allergy symptoms, and gut microbiota dysbiosis }\end{array}$ & $\begin{array}{c}\text { B, } 2 \mathrm{~g} / \mathrm{kg}, \text { p.o. } 7 \mathrm{~d} \\
\mathrm{~B}, 30 \mathrm{~m} / \mathrm{kg} \text {, p.o. } 7 \mathrm{~d} \\
\mathrm{~B}, 0.2 \% \text {, in diet } 8 \mathrm{w} \\
\mathrm{B}, 50 \mathrm{mg} / \mathrm{kg} \text {, p.o. } 6 \mathrm{~d} \\
\text { B, } 2 \mathrm{~g} / \mathrm{kg}, \text { p.o. } 14 \mathrm{~d} \\
\mathrm{~B}, 60 \mathrm{mg} / \mathrm{kg} \text {, p.o. } 37 \mathrm{~d}\end{array}$ & $\begin{array}{l}{[43]} \\
{[44]} \\
{[45]} \\
{[46]} \\
{[47]} \\
{[48]}\end{array}$ \\
\hline & $\begin{array}{l}\text { in NC/Nga mice with TNCB-induced AD } \\
\text { - Suppressed IgE, IL-4, IL-10, IL-31, TNF- } \alpha \text {, and } \\
\text { TSLP expression; MAPKs activity; and } \\
\text { NF-kB-independent Ikaros activation. } \\
\text { - Suppressed mast cell, Treg cell, and Langerhans } \\
\text { cell populations. } \\
\text { - Suppressed ear thickness, clinical skin severity, } \\
\text { and pruritic sensation }\end{array}$ & $\begin{array}{c}200 \mathrm{mg} / \mathrm{kg} \text {, p.o. } 10 \mathrm{~d} \\
200 \mathrm{mg} / \mathrm{kg} \text {, p.o. } 3 \mathrm{w} \\
200 \mathrm{mg} / \mathrm{kg} \text {, p.o. } 5 \mathrm{~d} \\
\text { 0.1\%, s.a. } 21 \mathrm{~d}\end{array}$ & $\begin{array}{l}{[49]} \\
{[50]} \\
{[51]} \\
{[52]}\end{array}$ \\
\hline & $\begin{array}{l}\text { in mice with DNCB/DNFB-induced AD } \\
\text { - Decreased IgE, IL-4,IL-6, IL-10, TSLP, TNF- } \alpha \text {, } \\
\text { nerve growth factor, and TARC expression and } \\
\text { MAPK and p70S6K signaling } \\
\text { Decreased ear swelling and dermatitis score }\end{array}$ & $\begin{array}{c}\text { B, } 0.1 \% \text {, s.a. } 2 \mathrm{w} \\
\mathrm{B}, 400 \mathrm{mg} / \mathrm{kg}, \text { p.o. } 6 \mathrm{w} \\
\text { B, } 1 \% \text {, s.a. } 8 \mathrm{~d} \\
\text { B, } 1 \% \text {, s.a. } 8 \mathrm{~d}\end{array}$ & $\begin{array}{l}{[53]} \\
{[54]} \\
{[55]} \\
{[56]}\end{array}$ \\
\hline & $\begin{array}{l}\text { in mice with oxazolone-induced } A D \\
\text { - Inhibited IL- } 1 \beta \text {, TNF- } \alpha \text {, and COX- } 2 \text { expression } \\
\text { Suppressed ear skin edema }\end{array}$ & $\mathrm{I}, 0.1 \%$, s.a. $7 \mathrm{~d}$ & [57] \\
\hline
\end{tabular}


Table 1. Cont.

\begin{tabular}{|c|c|c|c|}
\hline Ginseng & Effect & Dosage/Ad. Route & Ref \\
\hline & $\begin{array}{l}\text { in mice with pruritus } \\
\text { - Inhibited chloroquine-induced scratching, } \\
\text { histamine-induced scratching, and compound } \\
48 / 80 \text {-induced scratching behaviors } \\
\text { Inhibited histamine receptor type } 1 / \text { TRPV1 pathway } \\
\text { and } \mathrm{Ca}^{2+} \text { influx }\end{array}$ & $\begin{array}{l}\mathrm{I}, 100 \mathrm{mg} / \mathrm{m} \text {, p.o. } \\
\mathrm{I}, 50 \mathrm{mg} / \mathrm{m} \text {, p.o. } \\
\text { I, } 200 \mathrm{mg} / \mathrm{kg} \text {, p.o. } \\
\text { B, } 200 \mathrm{mg} / \mathrm{kg} \text {, p.o. }\end{array}$ & $\begin{array}{l}{[58]} \\
{[59]} \\
{[60]} \\
{[61]}\end{array}$ \\
\hline & $\begin{array}{l}\text { in mice with PCA reaction } \\
\text { - Inhibited IgE/antigen-induced PCA reaction } \\
\text { - } \quad \text { Inhibited the IgE/antigen-stimulated } \\
\text { degranulation, IL-4 expression, NF- } \mathrm{KB} \\
\text { activation in basophils }\end{array}$ & $\begin{array}{l}\mathrm{B}, 200 \mathrm{mg} / \mathrm{kg} \text {, p.o. } \\
\mathrm{I}, 50 \mathrm{mg} / \mathrm{kg} \text {, p.o. }\end{array}$ & $\begin{array}{l}{[61]} \\
{[62]}\end{array}$ \\
\hline WG & $\begin{array}{l}\text { in mice with OVA-sensitized asthma/rhinitis } \\
\text { - } \quad \text { Suppressed EMBP, IL-1 } \beta, \text { IL-4, and IL-5 } \\
\text { expression and MMPK activity } \\
\text { - } \quad \text { Suppressed IL-4, IL-5, and IL-13 expression and } \\
\text { immune cell infiltration }\end{array}$ & $\begin{array}{l}\mathrm{B}, 20 \mathrm{mg} / \mathrm{kg} \text {, i.p. } 3 \mathrm{~d} \\
\mathrm{~B}, 30 \mathrm{~m} / \mathrm{kg}, \text { p.o. } 7 \mathrm{~d}\end{array}$ & $\begin{array}{l}{[42]} \\
{[44]}\end{array}$ \\
\hline \multirow[t]{2}{*}{ fRG } & $\begin{array}{l}\text { in mice with OVA-sensitized asthma/rhinitis } \\
\text { - Inhibited nasal allergy symptoms and } \\
\text { gut dysbiosis } \\
\text { - Suppressed IgE, IL-4, and IL-5 expression and } \\
\text { mast cell, eosinophil, Th2 cell, } \\
\text { Th2/Th1 populations }\end{array}$ & $\begin{array}{l}\mathrm{B}, 0.2 \% \text {, in diet, } 8 \mathrm{w} \\
\mathrm{B}, 50 \mathrm{mg} / \mathrm{kg}, \text { p.o. } 6 \mathrm{~d} \\
\mathrm{~B}, 60 \mathrm{mg} / \mathrm{kg}, \text { p.o. } 37 \mathrm{~d}\end{array}$ & $\begin{array}{l}{[45]} \\
{[46]} \\
{[48]}\end{array}$ \\
\hline & $\begin{array}{l}\text { in mice with PCA reaction } \\
\text { - Inhibited IgE-DNP-stimulated passive } \\
\text { cutaneous anaphylaxis in mice } \\
\text { - Inhibited IgE-DNP-stimulated IL-4 expression } \\
\text { in RBH-2H3 mast cells }\end{array}$ & B, $50 \mathrm{mg} / \mathrm{kg}$, p.o. & [63] \\
\hline CG & $\begin{array}{l}\text { in NC/Nga mice with DNCB-induced AD } \\
\text { - Inhibited IgE; TNF- } \alpha / \text { IFN- } \gamma \text {-induced TARC, } \\
\text { TNF- } \alpha \text {, IFN- } \gamma \text {, IL-4, IL-5; and IL-13 expression } \\
\text { - } \quad \text { Ameliorated dermatitis severity }\end{array}$ & $20 \mathrm{mg} / \mathrm{kg}$, s.a. $4 \mathrm{w}$ & [64] \\
\hline BG & $\begin{array}{l}\text { in mice with DNCB-induced } A D \\
\text { - } \quad \text { Reduced IgE and IL-4 expression and } \\
\text { leukocyte populations } \\
\text { - } \quad \text { Alleviated the AD-like skin symptoms }\end{array}$ & $\mathrm{B}, 100 \mathrm{mg} / \mathrm{kg}$, s.a. $4 \mathrm{w}$ & [65] \\
\hline
\end{tabular}

$\mathrm{AD}$, atopic dermatitis; Ad, administered; B, Balb/c; BG, $\gamma$-irradiated black ginseng; CG, cultivated ginseng; COX, cyclooxygenase; d, day; DNCB, 1-chloro-2,4-dinitrobenzene; DNFB, 2,4-dinitrofluorobenzene; EMBP, eosinophil major basic protein; fRG, fermented red ginseng; I, ICR; IFN, interferon; iNOS, inducible NO synthase; m, mouse; MAPK, mitogen-activated protein kinase; MMCP, mucosal mast cell protease; OVA, ovalbumin; PCA, passive cutaneous anaphylaxis; p.o., per oral; s.a., skin application; TARC, thymus and activation-regulated chemokine; TNCB, 2,4,6-trinitro-1-chrolobenzene; TNF, tumor necrosis factor; Treg, regulatory T; TSLP, thymic stromal lymphopoietin; $\mathrm{w}$, week; WG, white ginseng.

In addition, Lee and Cho reported that RG suppressed mast cell populations, pruritic sensation, and IL-31 expression in NC/Nga mice with 2, 4, 6-trinitro-1-chrolobenzene (TNCB)-induced AD [49]. They also found that RG extract suppressed the ear thickness, IgE levels in the blood, and regulatory $\left(\mathrm{FOXP3}^{+}\right) \mathrm{T}$ cell and Langerhans cell $\left(\mathrm{CD} 1 \mathrm{a}^{+}\right)$populations in the lesions of TNCB-sensitized NC/Ng mice [50]. Treatment with RG inhibited thymic stromal lymphopoietin (TSLP) and TNF- $\alpha$ expression and Langerhans cell populations in NC/Nga mice with TNCB-induced AD [51]. Kim et al. reported that topical application of RG significantly suppressed the clinical skin severity score in NC/Nga mice with TNCB-induced AD [52]. Furthermore, RG treatment decreased the mast cell infiltration and TNF- $\alpha$ and IL-4 expression in the TNCB-exposed lesions but did not affect IgE levels in the blood. Sohn et al. reported that RG decreased IgE levels in the blood and IL-4 and IL-10 expression, MAPKs activity, and NF- $\mathrm{kB}$-independent Ikaros activation in the dorsal surface of mice with 1-chloro-2, 4-dinitrobenzene 
(DNCB)-induced AD [53]. RG decreased the IL-6, thymic stromal lymphopoietin (TSLP), and TNF- $\alpha$, and thymus and activation-regulated chemokine (TARC) expression; MAPKs activation; and dermatitis score in DNCB sensitized mice [54]. The topical pretreatment with RG prevented the induction of ear swelling, nerve growth factor expression, and nerve fiber extension in mice by exposure to 2, 4-dinitrofluorobenzene (DNFB) [55]. RG treatment suppressed mammalian target of rapamycin $(\mathrm{mTOR}) /$ p70 ribosomal protein S6 kinase (p70S6K) signaling in anti-FceRIa antibody-stimulated human basophil KH812 cells and DNFB-sensitized mice [56]. Choi et al. reported that cultivated Korean ginseng (CG) inhibited TNF- $\alpha /$ IFN- $\gamma$-induced thymus and activation-regulated chemokine (TARC) expression through NF-кB-dependent signaling in HaCaT cells [64]. Furthermore, CG ameliorated DNCB-induced atopic dermatitis severity; IgE and TARC expression in the blood; and TARC, TNF- $\alpha$, IFN- $\gamma$, IL-4, IL-5, and IL-13 expression in the skin lesions of mice. Bae et al. reported that RG suppressed oxazolone-induced ear skin edema, IL-1 $\beta, \mathrm{TNF}-\alpha$, and COX-2 expression in mice and inhibited iNOS and COX-2 expression in lipopolysaccharide-induced RAW264.7 cells [57]. Kang et al. reported that $\gamma$-irradiated black ginseng extract reduced the IgE/antigen-complex-induced degranulation in RBL-2H3 mast cells and alleviated the AD-like skin symptoms, IgE and IL-4 expression, and leukocyte populations in the blood [65]. These findings suggest that ginseng including RG and CG can suppress allergen-induced IgE level, TNF- $\alpha$, TSLP, IL-4, and IL-6 expression, resulting in the attenuation of AD.

Lee et al. reported that RG strongly inhibited chloroquine-induced scratching in mice [58]. Furthermore, RG inhibited chloroquine-induced $\mathrm{Ca}^{2+}$ influx in the primary culture of mouse dorsal root ganglia. RG also showed an anti-pruritic effect in mice with histamine-induced scratching by blocking the histamine-induced histamine receptor type 1/TRPV1 pathway in sensory neurons [59]. Trinh et al. reported that RG extract inhibited IgE/antigen-induced passive cutaneous anaphylaxis reaction in mice and inhibited the IgE/antigen-stimulated degranulation and IL-4 expression in basophils [60]. They also found that ginseng and RG extracts inhibited compound 48/80-induced scratching behaviors, IL-4 expression, and NF- $\mathrm{BB}$ activation in mice [61]. Hwang et al. reported that the fermentation of ginseng with Lactobacillus plantarum inhibited the IgE-DNP-stimulated IL-4 expression in $\mathrm{RBH}-2 \mathrm{H} 3$ mast cells and passive cutaneous anaphylaxis in mice [63]. Park and Park evaluated the effects of RG on the regeneration of the full-thickness skin wounds in rat [66]. They also found that oral or topical treatments with RG significantly suppressed the wound size and accelerated tissue regeneration rate. RG significantly increased the gene expression levels of transforming growth factor- $\beta 1$ and vascular endothelial growth factor during the early stages of wound healing. RG treatment increased matrix metalloproteinase (MMP)-1 and MMP-9 expression. Kim et al. reported that RG alleviated epidermal growth factor (EGF)-induced damage by blocking NF- $\mathrm{B}$ and ERK in NCI-H292 cells and EGF-stimulated human airway epithelial cells [67]. These results suggest that RG and fRG can alleviate anaphylaxis and pruritus by suppressing IgE level, IL-4 and IL-5 expression, and $N F-\kappa B$ activation.

Based on these findings, ginseng including RG and fRG alleviates the acute and chronic phases of allergic diseases by modulating the innate and adaptive immune cells. Thus, ginseng can suppress IgE, IL-4, and IL-5 expression and Th2-to-Th1 cell ratio through the modulation of mast cell, basophil, and eosinophil activation, resulting in the attenuation of AD, allergic rhinitis, asthma, and pruritus. The anti-allergic effects of WG and RG were enforced by the fermentation. Their constituents may affect several pathways involved in allergic diseases by specific and nonspecific action mechanisms. However, their anti-allergic effects can be influenced by the quality and quantity of anti-allergic constituents found in the ginseng and the administered route. Therefore, the preparation of ginseng products must be standardized and well-characterized. 


\subsection{Efficacy of Ginseng in Patients with Allergic Disorders}

A few reports are available on the clinical effectiveness of ginsengs against allergic disorders (Table 2). Kim et al. reported that in an 8-week, open, noncomparative clinical study of patients with AD, RG decreased eczema area and severity index score, transepidermal water loss, visual analogue scale, and sleep disturbance [68]. Jung et al. reported that in an open, noncomparative clinical study of patients with allergic rhinitis, RG alleviated rhinorrhea, nasal itching, and eye itching and suppressed IgE, IL-4 levels and eosinophil counts [69]. Park et al. reported that in a randomized, double-blind, placebo-controlled trial of patients with cold hypersensitivity in the hands and feet (CHHF), RG increased skin temperature of the hands and feet and decreased visual analog scale score of CHHF severity [70]. Jung et al. reported that in a 4-week, double-blind, placebo-controlled study of patients with persistent perennial allergic rhinitis, there was no significant difference in the total nasal symptom score between the fRG-treated and placebo groups in the experimental period, while the fRG-treated group, but not placebo group, showed the alleviation of nasal congestion [71]. These results suggest that RG and fRG may alleviate AD, allergic rhinitis, and cold hypersensitivity. Although several clinical trials have demonstrated effects of ginsengs in patients with allergic disorders, further controlled studies are required to clearly elucidate these effects.

Table 2. Summary of ginseng extract effects on allergic disorders.

\begin{tabular}{|c|c|c|}
\hline Ginseng & Effect & Ref \\
\hline \multirow{3}{*}{ RG } & $\begin{array}{l}\text { in an 8-week, open, noncomparative clinical study of patients with } A D(1-2 \mathrm{~g} / \text { day }) \\
\text { - decreased eczema area and severity index score, transepidermal water loss, } \\
\text { visual analogue scale } \\
\text { - } \quad \text { decreased sleep disturbance }\end{array}$ & [68] \\
\hline & $\begin{array}{l}\text { in an open, noncomparative clinical study of patients with allergic rhinitis }(3 \mathrm{mg} / \mathrm{kg} / \mathrm{day} \text {, } \\
4 \text { weeks) } \\
\text { - } \quad \text { alleviated rhinorrhea, nasal itching, and eye itching } \\
\text { - } \quad \text { suppressed IgE, IL-4 levels and eosinophil counts }\end{array}$ & [69] \\
\hline & $\begin{array}{l}\text { in a randomized, double-blind, placebo-controlled trial of patients with cold } \\
\text { hypersensitivity in the hands and feet }(\mathrm{CHHF})(1 \mathrm{~g} / \text { day, } 8 \text { weeks }) \\
\text { - } \quad \text { increased skin temperature of the hands and feet } \\
\text { - } \quad \text { decreased visual analog scale score of } \mathrm{CHHF} \text { severity }\end{array}$ & [70] \\
\hline fRG & $\begin{array}{l}\text { in double-blind, placebo-controlled study of patients with persistent perennial allergic } \\
\text { rhinitis ( } 750 \mathrm{mg} / \text { day, } 4 \text { weeks) } \\
\text { - Alleviated nasal congestion and the activities and emotions of quality of life. }\end{array}$ & [71] \\
\hline
\end{tabular}

\section{Anti-Allergic Effects of Ginseng Constituents}

In order to search for bioactive constituents of ginseng to treat allergic disorders, many researchers have examined the anti-allergic effectiveness of their constituent ginsenosides and polysaccharides in in vitro and in vivo studies [7,72,73] (Table 3). Of the ginsenosides, Rb1 inhibited IL-4 and GATA3 expression, airway resistance, and eosinophil population in the bronchoalveolar lavage fluid of ovalbumin-sensitized mice, while interferon- $\gamma($ IFN $\gamma)$ and T-bet expression were increased [74]. Rb1 also inhibited compound 48/80-induced scratching behaviors in mice, while the IgE/complex-induced degranulation and IL-4 expression were not affected in RBL-2H3 cells [60,61]. Ginsenoside Rd suppressed ovalbumin-induced expression of IgE, IL-4, IL-5, and IL-13 in nasal mucosa and bronchoalveolar lavage fluid and alleviated gut dysbiosis in mice, resulting in the attenuation of allergic rhinitis [46]. Ginsenoside Rd enhanced Th1-response to Candida albicans surface mannan extract in mice [75]. Wang et al. reported that, of tested ginsenosides Rb1, Rd, F2, CK, and 20(S)-protopanaxadiol, ginsenoside F2 most potently inhibited the compound 48/80-stimulated degranulation of mast cells and RBL-2H3 cells [76]. Oh et al. found that ginsenoside Rg1 significantly reduced ovalbumin-induced increases in TSLP, IL-1 $\beta$, and IL-4 expression; histamine and IgE levels; and eosinophil and mast cell 
populations in mice, while interferon- $\gamma$ expression was enhanced [77]. Ginsenoside Rg1 inhibited NF- $\mathrm{BB}$ signaling pathways in cultured mast cells in vitro [77]. The combination of ginsenoside Rg1 with aluminum hydroxide strongly induced immune responses to ovalbumin in mice [78]. Lee et al. reported that ginsenoside $\mathrm{Rg} 3$ inhibited chloroquine-induced $\mathrm{Ca}^{2+}$ influx in primary culture of mouse dorsal root ganglia [58]. Furthermore, ginsenoside Rg3 significantly reduced chloroquine-induced scratching in mice. Lee et al. reported that ginsenoside $\mathrm{Rg} 3$ inhibited NF- $\mathrm{kB}$ activation and COX-2 expression in IL-1 $\beta$-stimulated human asthmatic airway epithelial tissues [79]. Ginsenoside Rh2 attenuates allergic airway inflammation in ovalbumin-sensitized mice by regulating NF- $\mathrm{kB}$ activation and p38 MAPK phosphorylation [80]. RG saponin fraction and ginsenosides Rg3 and Rh2 inhibited compound 48/80or histamine-induced scratching behavior and vascular permeability [61]. Ginsenosides Rg3 and Rh2 inhibited IL-4 and TNF- $\alpha$ expression in IgE/antigen-complex-stimulated RBL-2H3 cells [61,81].

Bae et al. examined the inhibitory effects of ginsenosides Rg3, Rf, and Rh2 on IgE/antigen-complex-induced passive cutaneous anaphylaxis in mice [82]. Of these, ginsenoside $\mathrm{Rh} 2$ most potently inhibited the IgE/antigen-complex-induced passive cutaneous anaphylaxis reaction. Ginsenoside Rh2 strongly inhibited the IgE/antigen-complex-induced RBL-2H3 cell degranulation [82]. Ginsenoside Rh2 also inhibited oxazolone-induced expression of COX-2, IL-1 $\beta$, and TNF- $\alpha$ in the ears of mice, while the IL-4 expression was not affected [83]. Kim et al. reported that topical application of ginsenosides Rh2 or Rh2 plus Rg3 significantly reduced the clinical skin severity scores, ear thickness, mast cell populations, and TNF- $\alpha$ and IL-4 expression in the skin lesions of mice with TNCB-sensitized AD [52], while IFN $\gamma$ expression and IgE levels were not affected.

Oral administration of ginsenoside Rh1 reduced AD-like clinical symptoms, ear swelling, IL-4, and IgE levels in the skin lesions of hairless mice with oxazolone-induced AD, while IFN $\gamma$ and Foxp3 expression were increased [38]. Ginsenoside Rh1 also inhibited the release of histamine from rat peritoneal mast cells and the IgE/antigen-complex-induced passive cutaneous anaphylaxis reaction in mice. Ginsenoside Rh1 increased the membrane-stabilizing action in mast cells and inhibited COX-2 expression and NF- $\mathrm{BB}$ activation in RAW 264.7 cells. Park et al. reported that CK, a metabolite of ginsenoside $\mathrm{Rb} 1$, inhibited $\mathrm{NO}$ and prostaglandin E2 production in lipopolysaccharide-induced RAW 264.7 cells more strongly than the parental ginsenoside Rb1 [84]. CK also reduced the COX-2 expression and NF- $\mathrm{kB}$ activation. $\mathrm{CK}$ inhibited the IgE/antigen-complex-induced cell degranulation in RBL-2H3 cells and oxazolone-induced chronic dermatitis in mice [36]. Lin et al. reported that CK improved the accelerated and severe lupus nephritis in mice by blunting NLRP3 inflammasome activation and regulating $\mathrm{T}$ cell functions [85]. CK and its derivatives inhibited IgE production in mice with ovalbumin-sensitized asthma [86]. Shin et al. examined the anti-pruritic and vascular-permeability-inhibitory effects of ginsenoside $\mathrm{Rb} 1$ and its metabolite $\mathrm{CK}$ in mice with compound 48/80-, substance P-, or histamine-induced scratching behaviors [87]. When orally administered, ginsenoside $\mathrm{Rb} 1$ and $\mathrm{CK}$ both suppressed pruritic behaviors and skin vascular permeability. However, the intraperitoneal injection of ginsenoside $\mathrm{Rb} 1$ did not inhibit compound 48/80-induced scratching behaviors, while CK potently inhibited scratching behavior. Moreover, CK-fortified ginseng extract alleviated Dermatophagoides farinae body extract induced dermatitis score, ear thickness, scratching time, severity of skin lesions, and eosinophil and mast cell populations in NC/Nga mice [88]. These results suggest that ginsenosides and their metabolites can alleviate asthma, allergic rhinitis, AD, and scratching behavior by inhibiting IgE and IL-4 expression, NF- $\mathrm{kB}$ activation, and $\mathrm{Ca}^{2+}$ influx; increasing IFN $\gamma$ expression; and stabilizing the degranulation of mast cells and basophils. Of ginsenosides and their metabolites, the most absorbable ginsenosides Rh1 and CK the most potently can alleviate AD, allergic rhinitis, pruritus, and anaphylaxis in vivo and in vitro, followed by $\mathrm{Rd}$. 
Ginseng polysaccharides isolated from Panax japonicus or Panax ginseng, the immunity-potentiating anti-cancer agents, stimulated immune response; thus, they activate phagocytosis, natural killer cell activity, and cytotoxic T cell activity [89]. Furthermore, they activate the phagocytosis of neutrophils and macrophages [90]. Ginsan isolated from Panax ginseng reduced ovalbumin-sensitized IL-5 expression and airway hyperresponsiveness, remodeling, and eosinophilia in mice, resulting in the attenuation of asthma [91]. RG-II isolated from Panax ginseng induced the Th1/Th2 immune response and IFN $\gamma$ expression in mice with ovalbumin-induced asthma, while IL-4 and GATA3 expression and eosinophil populations were decreased in the bronchoalveolar lavage fluid [92]. CVT-E002 derived from North American Ginseng also activated Th1 responses and increased IL-10 expression, resulting in the attenuation of allergic airway inflammation and airway hyperresponsiveness [93]. These suggest that ginseng polysaccharides can stimulate the Th1 cell immune responses, resulting in the attenuation of asthma with the suppression of Th2 cell activation.

In addition, Lee et al. reported that oral intake of Korean ginseng could induce anaphylaxis in occupational settings by non-IgE-dependently activating basophil/mast cells [94]. Hon and Leung et al. reported that urticarial could occur in a feeding neonate, whose mother took American ginseng [95]. Erdle et al. reported that a child experienced anaphylaxis after inhaling powered American ginseng [96]. These results suggest that ginseng must be carefully used in clinic, because it can cause side effects due to its allergic reactions.

Table 3. Summary of ginseng constituent effects on allergic disorders.

\begin{tabular}{|c|c|c|}
\hline Constituent & Effect & Ref \\
\hline Ginsenoside Rb1 & $\begin{array}{l}\text { - Suppressed IL-4 and GATA3 expression, airway } \\
\text { resistance, and eosinophil cell population and increased } \\
\text { IFN } \gamma \text { and T-bet expression in ovalbumin-sensitized mice } \\
\text { - Inhibited compound 48/80-induced scratching behaviors } \\
\text { in mice } \\
\text { - Inhibited NO and prostaglandin E2 production in } \\
\text { LPS-induced RAW } 264.7 \text { cells } \\
\text { - Inhibited IgE/antigen-induced degranulation of RBL-2H3 } \\
\text { cells and PCA reaction in mice } \\
\text { Inhibited compound } 48 / 80 \text {-stimulated degranulation of } \\
\text { mast cells and RBL-2H3 cells. }\end{array}$ & {$[36,60,62,74,84]$} \\
\hline Ginsenoside Re & $\begin{array}{l}\text { - Suppressed histamine-induced IL- } 4 \text { and TNF- } \alpha \\
\text { expression, NF-kB and c-jun activation, and scratching } \\
\text { behaviors in mice }\end{array}$ & {$[38,97]$} \\
\hline Ginsenoside Rd & $\begin{array}{l}\text { - Suppressed IgE, IL-4, IL-5, and IL-13 expression and } \\
\text { allergic rhinitis and gut dysbiosis in } \\
\text { ovalbumin-sensitized mice } \\
\text { Enhanced Th1-response to Candida albicans surface } \\
\text { mannan extract in mice } \\
\text { - Inhibited compound } 48 / 80 \text {-stimulated degranulation of } \\
\text { mast cells and RBL-2H3 cells }\end{array}$ & {$[46,75]$} \\
\hline Ginsenoside Rg1 & $\begin{array}{l}\text { - Reduced TSLP, IL-1 } 1 \beta \text {, and IL-4 expression; histamine and } \\
\text { IgE secretion; and eosinophil and mast cell populations } \\
\text { and increased IFN } \gamma \text { expression in } \\
\text { ovalbumin-induced mice } \\
\text { - Inhibited NF- } \mathrm{kB} \text { signaling pathways in cultured } \\
\text { mast cells } \\
\text { - Induced immune responses to OVA in mice by the } \\
\text { combination with aluminum hydroxide }\end{array}$ & {$[77,78]$} \\
\hline
\end{tabular}


Table 3. Cont.

\begin{tabular}{|c|c|c|}
\hline Constituent & Effect & Ref \\
\hline Ginsenoside Rg3 & 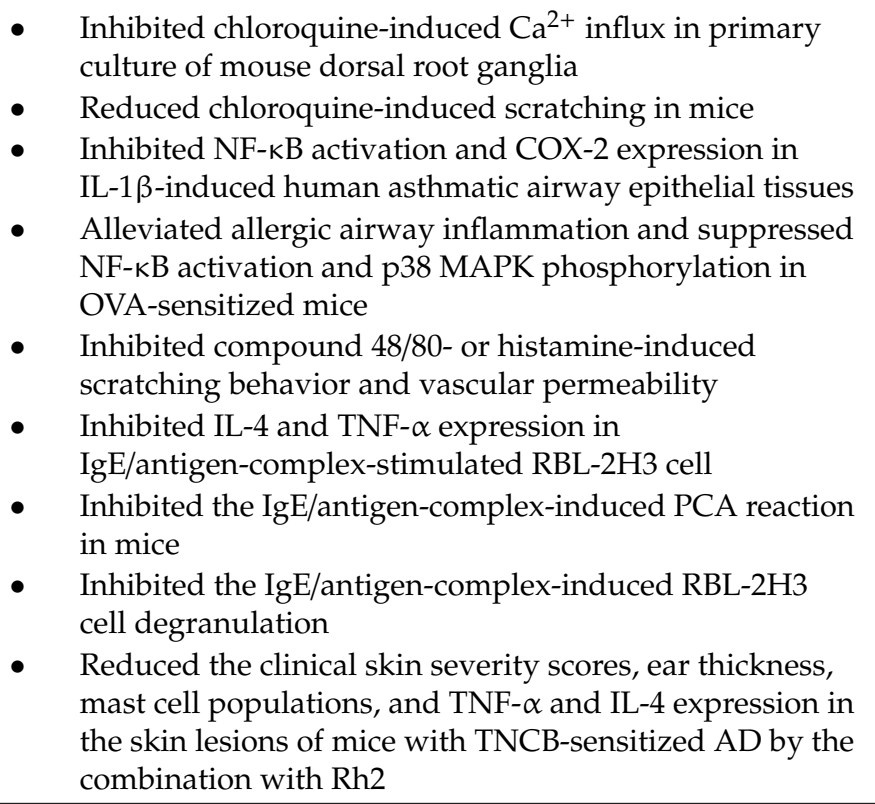 & {$[52,58,79,82]$} \\
\hline Ginsenoside Rh2 & $\begin{array}{l}\text { - Suppressed allergic airway inflammation and suppressed } \\
\text { NF-kB activation and p38 MAPK phosphorylation in } \\
\text { OVA-sensitized mice } \\
\text { - } \quad \text { Inhibited compound 48/80- or histamine-induced } \\
\text { scratching behavior and vascular permeability } \\
\text { - Inhibited IL-4 and TNF- } \alpha \text { expression in } \\
\text { IgE/antigen-complex-stimulated RBL-2H3 cell } \\
\text { Inhibited the IgE/antigen-complex-induced PCA reaction } \\
\text { in mice } \\
\text { - Inhibited the IgE/antigen-complex-induced RBL-2H3 } \\
\text { cell degranulation } \\
\text { Inhibited oxazolone-induced expression of COX-2, IL-1 } \beta \text {, } \\
\text { and TNF- } \gamma \text { in the ears of mice } \\
\text { Reduced the clinical skin severity scores, ear thickness, } \\
\text { mast cell populations, and TNF- } \alpha \text { and IL-4 expression in } \\
\text { the skin lesions of mice with TNCB-sensitized AD }\end{array}$ & {$[52,61,80-83]$} \\
\hline Ginsenoside Rh1 & $\begin{array}{l}\text { Reduced AD-like clinical symptoms, ear swellings, IL-4, } \\
\text { and IgE expression and increased IFN } \gamma \text { and Foxp3 in } \\
\text { mice with oxazolone-induced AD } \\
\text { Inhibited the release of histamine from rat peritoneal } \\
\text { mast cells and the IgE/antigen-complex-induced PCA } \\
\text { reaction in mice } \\
\text { - Increased the membrane-stabilizing action in mast cells } \\
\text { - Inhibited COX-2 expression and NF- } \mathrm{B} \text { B activation in } \\
\text { RAW } 264.7 \text { cells } \\
\text { Inhibited histamine-induced IL-4 and TNF- } \alpha \text { expression, } \\
\text { NF- } \kappa \mathrm{B} \text { and c-jun activation, and scratching behaviors } \\
\text { in mice }\end{array}$ & {$[38,97]$} \\
\hline
\end{tabular}


Table 3. Cont.

\begin{tabular}{|c|c|c|}
\hline Constituent & Effect & Ref \\
\hline $\begin{array}{l}\text { Compound K } \\
\text { (CK) }\end{array}$ & $\begin{array}{l}\text { - Inhibited NO and prostaglandin E2 production, COX-2 } \\
\text { expression, and NF- } \mathrm{KB} \text { activation in LPS-induced RAW } \\
264.7 \text { cells } \\
\text { Inhibited IgE/antigen-complex-induced cell } \\
\text { degranulation in RBL-2H3 cells and oxazolone-induced } \\
\text { chronic dermatitis in mice } \\
\text { - Improved the accelerated and severe lupus nephritis } \\
\text { in mice } \\
\text { - Inhibited IgE production in mice with } \\
\text { ovalbumin-sensitized asthma } \\
\text { Inhibited compound } 48 / 80-\text {, substance P-, or } \\
\text { histamine-induced scratching behaviors and vascular } \\
\text { permeability in mice } \\
\text { Inhibited IgE/antigen-induced degranulation of RBL-2H3 } \\
\text { cells and PCA reaction in mice } \\
\text { Inhibited compound } 48 / 80-\text {-stimulated degranulation of } \\
\text { mast cells and RBL-2H3 cells } \\
\text { (CK-fortified ginseng extract) Alleviated } \\
\text { Dermatophagoides farinae body extract induced dermatitis } \\
\text { score, ear thickness, scratching time, severity of skin } \\
\text { lesions, and eosinophil and mast cell populations in } \\
\text { NC/Nga mice }\end{array}$ & {$[36,62,84-88]$} \\
\hline Polysaccharide & $\begin{array}{l}\text { Ginsan } \\
\text { - Reduced ovalbumin-sensitized IL-5 expression and } \\
\text { airway hyperresponsiveness, remodeling, and } \\
\text { eosinophilia (asthma) in mice } \\
R G-I I \\
\text { - Induced the Th1/Th2 immune response and IFN } \gamma \\
\text { expression and suppressed IL-4 and GATA3 expression } \\
\text { and eosinophil populations in mice with } \\
\text { ovalbumin-induced asthma } \\
\text { CVT-E002 } \\
\text { Activated Th1 responses, increased IL-10 expression, } \\
\text { suppressed allergic airway inflammation and } \\
\text { airway hyperresponsiveness }\end{array}$ & [91-93] \\
\hline
\end{tabular}

\section{Gut Microbiota Enforce Anti-Allergic Activities of Ginseng Constituents}

Ginseng extracts and their constituents, particularly ginsenosides, showed anti-allergic effects in the in vivo studies. However, the absorption of these ginsenosides into the blood is not easy due to their hydrophilicity. Therefore, they are metabolized by gut microbiota in the intestine, which transform hydrophilic ginsenosides such as ginsenosides $\mathrm{Rb} 1, \mathrm{Rb} 2$, and Re into hydrophobic ginsenosides such as CK and Rh1 [13,20,97,98]. Comparing the anti-allergic activities of naïve ginsenosides Rb1, Rg3, and Re to those of their metabolite ginsenosides $\mathrm{CK}, \mathrm{Rh} 2$, and Rh1, metabolites (ginsenosides CK, $\mathrm{Rh} 2$, and Rh1) suppress allergic reactions such as passive cutaneous anaphylaxis, scratching, and asthma more potently than parental ginsenosides $\mathrm{Rb} 1, \mathrm{Rg} 3$, and Re, respectively $[38,62,81,82,93]$. However, oral gavage of antibacterials suppresses their biotransformations and attenuates anti-allergic activities in mice. For example, when antibiotics (cefadroxil, oxytetracycline, and erythromycin mixture; $\mathrm{COE})$, are orally gavaged, the fecal ginsenoside Re-metabolizing $\beta$-glucosidase and $\alpha$-rhamnosidase activities and production of the metabolite ginsenoside Rh1 production are significantly suppressed [98]. The metabolism of ginsenoside $\mathrm{Rb} 1$ by gut microbiota is also inhibited by antibiotic treatment $[31,97,98]$. Furthermore, the anti-allergic activity of orally gavaged ginsenoside Re is significantly attenuated 
in mice treated with $\mathrm{COE}$, but that of orally gavaged ginsenoside Rh1 are not affected. Oral gavage of ginsenoside Rh1 inhibits IL-4 and TNF- $\alpha$ expression and NF- $\mathrm{kB}$ and c-jun activation in mice with histamine-stimulated scratching more potently than parental ginsenoside Re. These results suggest that orally administered ginseng extracts and their hydrophilic ginsenosides should be metabolized to hydrophobic ginsenosides by gut microbiota, which enhances their anti-allergic activity, and, when simultaneously treated with antibacterials, their anti-allergic activities are attenuated. In addition, ginseng extract has been reported to rarely activate allergic responses rather than attenuate allergic disorders [95-97]. However, the mechanism should be clarified to safely use ginseng for the treatment of allergic disorders in clinics.

\section{Conclusions}

Herein, we discussed the current knowledge related to the effectiveness of ginseng on allergic disorders including asthma, allergic rhinitis, AD, and pruritus. Many studies are limited in examining the effectiveness of ginseng, including red ginseng and fRG and their constituent ginsenosides Rb1, $\mathrm{Rd}$, and Rg3, against allergic disorders. Nevertheless, ginseng extracts alleviate allergic disorders such as asthma, allergic rhinitis, AD, and pruritus by inhibiting IgE, IL-4, and IL-5 expression through the modulation of mast cells, eosinophils, and Th1-to-Th2 ratio (Figure 3). Of ginseng extracts, fRG most potently alleviates allergic disorders, followed by RG and WG. Of their ginsenosides, CK, Rh1, and Rh2, which are the metabolites from hydrophilic parental ginsenosides by gut microbiota, strongly alleviated allergic disorders. To enforce these metabolites, fRG was developed. These ginseng constituents, absorbable into the blood, should express pharmacological effects, and the pharmacological activities of ginseng extracts may be dependent on the absorbable metabolites produced by gut microbiota. Ginseng itself can be allergen. Moreover, the great part of these results are inconclusive in the quality and quantity of anti-allergic constituents found in the ginseng and the administered route. Therefore, the anti-allergic effects of ginseng must be supported by further clinical and in-depth in vitro and in vivo studies.

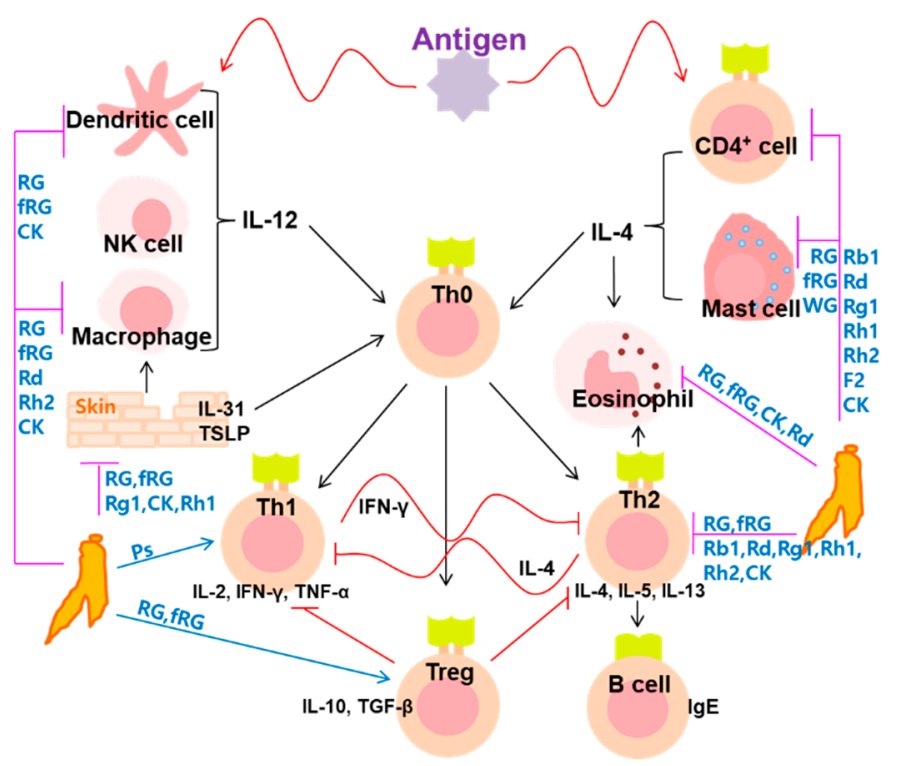

Figure 3. The hypothetical antiallergic action mechanisms of ginseng and ginsenosides. CK, compound $\mathrm{K}$; fRG, fermented red ginseng; RG, red ginseng; WG, white ginseng.

Author Contributions: M.J.H. and D.-H.K. conceived the idea for this study. M.J.H. and D.-H.K. designed the study. M.J.H. and D.-H.K. analyzed the data. M.J.H. and D.-H.K. wrote the main manuscript text. All authors reviewed and approved the contents of the manuscript. 
Conflicts of Interest: The authors declare no conflict of interest. The funders had no role in the design of the study, in the collection, analyses, or interpretation of data, in the writing of the manuscript, or in the decision to publish the results.

\section{References}

1. Stephani, J.; Radulović, K.; Niess, J.H. Gut Microbiota, Probiotics and Inflammatory Bowel Disease. Arch. Immunol. Ther. Exp. 2011, 59, 161-177. [CrossRef]

2. Skoner, D.P. Allergic rhinitis: Definition, epidemiology, pathophysiology, detection, and diagnosis. J. Allergy Clin. Immunol. 2001, 108, S2-S8. [CrossRef] [PubMed]

3. Braido, F.; Sclifò, F.; Ferrando, M.; Canonica, G.W. New Therapies for Allergic Rhinitis. Curr. Allergy Asthma Rep. 2014, 14, 422. [CrossRef]

4. Ricketti, P.A.; Alandijani, S.; Lin, C.H.; Casale, T. Investigational new drugs for allergic rhinitis. Expert Opin. Investig. Drugs 2017, 26, 279-292. [CrossRef] [PubMed]

5. Aaronson, D.W. Side effects of rhinitis medications. J. Allergy Clin. Immunol. 1998, 101, S379-S382. [CrossRef]

6. Cox, L.S. How safe are the biologicals in treating asthma and rhinitis? Allergy Asthma Clin. Immunol. 2009, 5 , 4. [CrossRef]

7. Bielory, L. Complementary and alternative interventions in asthma, allergy, and immunology. Ann. Allergy Asthma Immunol. 2004, 93, S45-S54. [CrossRef]

8. Kulka, M. The potential of natural products as effective treatments for allergic inflammation: Implications for allergic rhinitis. Curr. Top. Med. Chem. 2009, 9, 1611-1624. [CrossRef]

9. Attele, A.S.; Wu, J.A.; Yuan, C.-S. Ginseng pharmacology: Multiple constituents and multiple actions. Biochem. Pharmacol. 1999, 58, 1685-1693. [CrossRef]

10. Kim, D.-H. Chemical Diversity of Panax ginseng, Panax quinquifolium, and Panax notoginseng. J. Ginseng Res. 2012, 36, 1-15. [CrossRef]

11. Mancuso, C.; Santangelo, R. Panax ginseng and Panax quinquefolius: From pharmacology to toxicology. Food Chem. Toxicol. 2017, 107, 362-372. [CrossRef] [PubMed]

12. Nocerino, E.; Amato, M.; Izzo, A.A. The aphrodisiac and adaptogenic properties of ginseng. Fitoterapia 2000, 71, S1-S5. [CrossRef]

13. Zhao, B.; Lv, C.; Lu, J. Natural occurring polysaccharides from Panax ginseng C. A. Meyer: A review of isolation, structures, and bioactivities. Int. J. Boil. Macromol. 2019, 133, 324-336. [CrossRef] [PubMed]

14. Shibata, S. Chemistry and cancer preventing activities of ginseng saponins and some related triterpenoid compounds. J. Korean Med Sci. 2001, 16, S28-S37. [CrossRef] [PubMed]

15. Yoshikawa, M.; Murakami, T.; Yashiro, K.; Yamahara, J.; Matsuda, H.; Saijoh, R.; Tanaka, O. Bioactive saponins and glycosides. XI. Structures of new dammarane-type triterpene oligoglycosides, quinquenosides I, II, III, IV, and V, from American ginseng, the roots of Panax quinquefolium L. Chem. Pharm. Bull. 1998, 46, 647-654. [CrossRef]

16. Zhu, G.-Y.; Li, Y.-W.; Hau, D.K.-P.; Jiang, Z.-H.; Yu, Z.-L.; Fong, W.-F. Protopanaxatriol-Type Ginsenosides from the Root of Panax ginseng. J. Agric. Food Chem. 2011, 59, 200-205. [CrossRef]

17. Zhang, S.; Chen, C.; Lu, W.; Wei, L. Phytochemistry, pharmacology, and clinical use of Panax notoginseng flowers buds. Phytother. Res. 2018, 32, 2155-2163. [CrossRef]

18. Yang, W.; Hu, Y.; Wu, W.-Y.; Ye, M.; Guo, D.-A. Saponins in the genus Panax, L. (Araliaceae): A systematic review of their chemical diversity. Phytochemistry 2014, 106, 7-24. [CrossRef]

19. Liu, Y.; Zhao, J.; Chen, Y.; Li, W.; Li, B.; Jian, Y.; Sabir, G.; Cheng, S.; Tuo, Q.; Khan, I.; et al. Polyacetylenic Oleanane-Type Triterpene Saponins from the Roots of Panax japonicus. J. Nat. Prod. 2016, 79, 3079-3085. [CrossRef]

20. Choi, K.-T. Botanical characteristics, pharmacological effects and medicinal components of KoreanPanax ginsengC A Meyer. Acta Pharmacol. Sin. 2008, 29, 1109-1118. [CrossRef]

21. Akao, T.; Kanaoka, M.; Kobashi, K. Appearance of compound K, a major metabolite of ginsenoside Rb1 by intestinal bacteria, in rat plasma after oral administration-measurement of compound $\mathrm{K}$ by enzyme immunoassay. Boil. Pharm. Bull. 1998, 21, 245-249. [CrossRef] [PubMed] 
22. Abdel-Tawab, M.; Bahr, U.; Karas, M.; Wurglics, M.; Schubert-Zsilavecz, M. DEGRADATION OF GINSENOSIDES IN HUMANS AFTER ORAL ADMINISTRATION. Drug Metab. Dispos. 2003, 31, 1065-1071. [CrossRef] [PubMed]

23. Akao, T.; Kida, H.; Kanaoka, M.; Hattori, M.; Kobashi, K. Drug Metabolism: Intestinal Bacterial Hydrolysis is Required for the Appearance of Compound K in Rat Plasma after Oral Administration of Ginsenoside Rb1 from Panax ginseng. J. Pharm. Pharmacol. 1998, 50, 1155-1160. [CrossRef]

24. Kobashi, K.; Akao, T. Relation of Intestinal Bacteria to Pharmacological Effects of Glycosides. Biosci. Microflora 1997, 16, 1-7. [CrossRef]

25. Kim, D.H. Herbal medicines are activated by intestinal microflora. Nat. Prod. Sci. 2002, 8, 35-43.

26. Bae, E.-A.; Park, S.-Y.; Kim, D.-H. Constitutive beta-glucosidases hydrolyzing ginsenoside Rb1 and Rb2 from human intestinal bacteria. Boil. Pharm. Bull. 2000, 23, 1481-1485. [CrossRef]

27. Bae, E.-A.; Han, M.J.; Kim, E.-J.; Kim, D.-H. Transformation of ginseng saponins to ginsenoside Rh2 by acids and human intestinal bacteria and biological activities of their transformants. Arch. Pharmacal Res. 2004, 27, 61-67. [CrossRef]

28. Kim, D.-H. Gut microbiota-mediated pharmacokinetics of ginseng saponins. J. Ginseng Res. 2018, 42, $255-263$. [CrossRef]

29. Kim, K.-A.; Yoo, H.H.; Gu, W.; Yu, D.-H.; Jin, M.J.; Choi, H.-L.; Yuan, K.; Guérin-Deremaux, L.; Kim, D.-H. A prebiotic fiber increases the formation and subsequent absorption of compound $\mathrm{K}$ following oral administration of ginseng in rats. J. Ginseng Res. 2014, 39, 183-187. [CrossRef]

30. Kim, D.-H. Gut Microbiota-Mediated Drug-Antibiotic Interactions. Drug Metab. Dispos. 2015, 43, 1581-1589. [CrossRef]

31. Xu, R.; Peng, Y.; Wang, M.; Fan, L.; Li, X. Effects of broad-spectrum antibiotics on the metabolism and pharmacokinetics of ginsenoside Rb1: A study on rats' gut microflora influenced by lincomycin. J. Ethnopharmacol. 2014, 158, 338-344. [CrossRef] [PubMed]

32. Kim, J.-K.; Kim, J.-Y.; Jang, S.-E.; Choi, M.-S.; Jang, H.-M.; Yoo, H.-H.; Kim, N.-H. Fermented Red Ginseng Alleviates Cyclophosphamide-Induced Immunosuppression and 2,4,6-Trinitrobenzenesulfonic Acid-Induced Colitis in Mice by Regulating Macrophage Activation and T Cell Differentiation. Am. J. Chin. Med. 2018, 46, 1879-1897. [CrossRef] [PubMed]

33. Kim, J.-K.; Choi, M.S.; Jeung, W.; Ra, J.; Yoo, H.H.; Kim, D.-H. Effects of gut microbiota on the pharmacokinetics of protopanaxadiol ginsenosides Rd, Rg3, F2, and compound $\mathrm{K}$ in healthy volunteers treated orally with red ginseng. J. Ginseng Res. 2019. [CrossRef]

34. Liu, H.; Yang, J.; Du, F.; Gao, X.; Ma, X.; Huang, Y.; Xu, F.; Niu, W.; Wang, F.; Mao, Y.; et al. Absorption and Disposition of Ginsenosides after Oral Administration of Panax notoginseng Extract to Rats. Drug Metab. Dispos. 2009, 37, 2290-2298. [CrossRef] [PubMed]

35. Lee, H.-U.; Bae, E.-A.; Han, M.J.; Kim, N.-J.; Kim, D.-H. Hepatoprotective effect of ginsenoside Rb1 and compound K on tert-butyl hydroperoxide-induced liver injury. Liver Int. 2005, 25, 1069-1073. [CrossRef] [PubMed]

36. Shin, Y.-W.; Bae, E.-A.; Kim, S.-S.; Lee, Y.-C.; Kim, N.-H. Effect of ginsenoside Rb1 and compound K in chronic oxazolone-induced mouse dermatitis. Int. Immunopharmacol. 2005, 5, 1183-1191. [CrossRef]

37. Kim, T.W.; Choi, H.-J.; Kim, N.-J.; Kim, N.-H. Anxiolytic-like Effects of Ginsenosides Rg3 and Rh2 from Red Ginseng in the Elevated Plus-Maze Model. Planta Med. 2009, 75, 836-839. [CrossRef]

38. Park, E.-K.; Choo, M.-K.; Han, M.J.; Kim, D.-H. Ginsenoside Rh1 Possesses Antiallergic and Anti-Inflammatory Activities. Int. Arch. Allergy Immunol. 2004, 133, 113-120. [CrossRef]

39. Gu, W.; Kim, K.-A.; Kim, D.-H. Ginsenoside Rh1 ameliorates high fat diet-induced obesity in mice by inhibiting adipocyte differentiation. Boil. Pharm. Bull. 2013, 36, 102-107. [CrossRef]

40. Lee, S.-Y.; Jeong, J.-J.; Eun, S.-H.; Kim, D.-H. Anti-inflammatory effects of ginsenoside Rg1 and its metabolites ginsenoside Rh1 and 20(S)-protopanaxatriol in mice with TNBS-induced colitis. Eur. J. Pharmacol. 2015, 762, 333-343. [CrossRef]

41. Inoue, K.-I. Korean red ginseng for allergic rhinitis. Immunopharmacol. Immunotoxicol. 2013, $35,693$. [CrossRef] [PubMed]

42. Kim, D.Y.; Yang, W.M. Panax ginseng ameliorates airway inflammation in an ovalbumin-sensitized mouse allergic asthma model. J. Ethnopharmacol. 2011, 136, 230-235. [CrossRef] [PubMed] 
43. Babayigit, A.; Olmez, D.; Karaman, O.; Bagriyanik, H.A.; Yilmaz, O.; Kivcak, B.; Erbil, G.; Uzuner, N. Ginseng ameliorates chronic histopathologic changes in a murine model of asthma. Allergy Asthma Proc. 2008, 29, 493-498. [CrossRef] [PubMed]

44. Lim, C.-Y.; Moon, J.-M.; Kim, B.-Y.; Lim, S.-H.; Lee, G.-S.; Yu, H.-S.; Cho, S. Comparative study of Korean White Ginseng and Korean Red Ginseng on efficacies of OVA-induced asthma model in mice. J. Ginseng Res. 2014, 39, 38-45. [CrossRef] [PubMed]

45. Lee, E.-J.; Song, M.-J.; Kwon, H.-S.; Ji, G.E.; Sung, M.-K. Oral administration of fermented red ginseng suppressed ovalbumin-induced allergic responses in female BALB/c mice. Phytomedicine 2012, 19, 896-903. [CrossRef]

46. Kim, H.I.; Kim, J.-K.; Kim, J.-Y.; Han, M.J.; Kim, D.-H. Fermented red ginseng and ginsenoside Rd alleviate ovalbumin-induced allergic rhinitis in mice by suppressing IgE, interleukin-4, and interleukin-5 expression. J. Ginseng Res. 2019, 43, 635-644. [CrossRef]

47. Jung, J.H.; Kang, I.G.; Kim, D.; Hwang, Y.J.; Kim, S.T. The effect of Korean red ginseng on allergic inflammation in a murine model of allergic rhinitis. J. Ginseng Res. 2013, 37, 167-175. [CrossRef]

48. Sumiyoshi, M.; Sakanaka, M.; Kimura, Y. Effects of Red Ginseng extract on allergic reactions to food in Balb/c mice. J. Ethnopharmacol. 2010, 132, 206-212. [CrossRef]

49. Lee, H.J.; Cho, S.H. Therapeutic Effects of Korean Red Ginseng Extract in a Murine Model of Atopic Dermatitis: Anti-pruritic and Anti-inflammatory Mechanism. J. Korean Med Sci. 2017, 32, 679-687. [CrossRef]

50. Lee, J.H.; Cho, S.H. Korean red ginseng extract ameliorates skin lesions in NC/Nga mice: An atopic dermatitis model. J. Ethnopharmacol. 2011, 133, 810-817. [CrossRef]

51. Cho, E.; Cho, S.H. Effects of Korean red ginseng extract on the prevention of atopic dermatitis and its mechanism on early lesions in a murine model. J. Ethnopharmacol. 2013, 145, 294-302. [CrossRef] [PubMed]

52. Kim, H.S.; Kim, N.H.; Kim, B.K.; Yoon, S.K.; Kim, M.H.; Lee, J.Y.; Kim, H.O.; Park, Y.M. Effects of topically applied Korean red ginseng and its genuine constituents on atopic dermatitis-like skin lesions in NC/Nga mice. Int. Immunopharmacol. 2011, 11, 280-285. [CrossRef] [PubMed]

53. Sohn, E.-H.; Jang, S.-A.; Lee, C.-H.; Jang, K.-H.; Kang, S.-C.; Park, H.-J.; Pyo, S. Effects of Korean Red Ginseng Extract for the Treatment of Atopic Dermatitis-Like Skin Lesions in Mice. J. Ginseng Res. 2011, 35, 479-486. [CrossRef] [PubMed]

54. Park, J.-H.; Ahn, E.-K.; Ko, H.-J.; Lee, J.Y.; Hwang, S.-M.; Ko, S.; Oh, J.S. Korean red ginseng water extract alleviates atopic dermatitis-like inflammatory responses by negative regulation of mitogen-activated protein kinase signaling pathway in vivo. Biomed. Pharmacother. 2019, 117, 109066. [CrossRef] [PubMed]

55. Samukawa, K.; Izumi, Y.; Shiota, M.; Nakao, T.; Osada-Oka, M.; Miura, K.; Iwao, H. Red ginseng inhibits scratching behavior associated with atopic dermatitis in experimental animal models. J. Pharmacol. Sci. 2012, 118, 391-400. [CrossRef]

56. Osada-Oka, M.; Hirai, S.; Izumi, Y.; Misumi, K.; Samukawa, K.; Tomita, S.; Miura, K.; Minamiyama, Y.; Iwao, H. Red ginseng extracts attenuate skin inflammation in atopic dermatitis through p70 ribosomal protein S6 kinase activation. J. Pharmacol. Sci. 2018, 136, 9-15. [CrossRef] [PubMed]

57. Bae, E.A.; Han, M.J.; Shin, Y.W.; Kim, D.H. Antiallergic and antipsoriatic effects of Korean red ginseng. J. Ginseng Res. 2005, 29, 80-85.

58. Lee, W.J.; Kim, Y.S.; Shim, W.S. Korean Red Ginseng extract and ginsenoside Rg3 have anti-pruritic effects on chloroquine-induced itch by inhibition of MrgprA3/TRPA1-mediated pathway. J. Ginseng Res. 2018, 42, 470-475. [CrossRef]

59. Jang, Y.; Lee, W.-J.; Hong, G.-S.; Shim, W.-S. Red ginseng extract blocks histamine-dependent itch by inhibition of H1R/TRPV1 pathway in sensory neurons. J. Ginseng Res. 2015, 39, 257-264. [CrossRef] [PubMed]

60. Trinh, H.T.; Bae, E.A.; Han, M.J.; Shin, Y.W.; Kim, D.H. Inhibitory effects of red ginseng on passive cutaneous anaphylaxis and scratching behavior reactions in mice. J. Ginseng Res. 2007, 31, 137-141.

61. Trinh, H.-T.; Han, M.; Shin, Y.-W.; Han, S.-J.; Kim, N.-H. Evaluation of Antipruritic Effects of Red Ginseng and Its Ingredients in Mice. Planta Med. 2008, 74, 210-214. [CrossRef] [PubMed]

62. Choo, M.-K.; Park, E.-K.; Han, M.J.; Kim, N.-H. Antiallergic Activity of Ginseng and its Ginsenosides. Planta Med. 2003, 69, 518-522. [CrossRef] [PubMed] 
63. Hwang, S.-W.; Sun, X.; Han, J.-H.; Kim, T.-Y.; Koppula, S.; Kang, T.-B.; Hwang, J.-K.; Lee, K.H. Fermentation-Mediated Enhancement of Ginseng's Anti-Allergic Activity against IgE-Mediated Passive Cutaneous Anaphylaxis In Vivo and In Vitro. J. Microbiol. Biotechnol. 2018, 28, 1626-1634. [CrossRef] [PubMed]

64. Choi, J.H.; Jin, S.W.; Park, B.H.; Kim, H.G.; Khanal, T.; Han, H.J.; Hwang, Y.P.; Choi, J.M.; Chung, Y.C.; Hwang, S.K.; et al. Cultivated ginseng inhibits 2,4-dinitrochlorobenzene-induced atopic dermatitis-like skin lesions in NC/Nga mice and TNF- $\alpha /$ IFN- $\gamma$-induced TARC activation in HaCaT cells. Food Chem. Toxicol. 2013, 56, 195-203. [CrossRef]

65. Kang, J.A.; Song, H.-Y.; Byun, E.-H.; Ahn, N.-G.; Kim, H.-M.; Nam, Y.R.; Lee, G.H.; Jang, B.-S.; Choi, D.S.; Lee, D.-E.; et al. Gamma-irradiated black ginseng extract inhibits mast cell degranulation and suppresses atopic dermatitis-like skin lesions in mice. Food Chem. Toxicol. 2018, 111, 133-143. [CrossRef]

66. Park, K.-S.; Park, D.H. The effect of Korean Red Ginseng on full-thickness skin wound healing in rats. J. Ginseng Res. 2018, 43, 226-235. [CrossRef]

67. Kim, J.-H.; Kang, J.W.; Kim, M.; Lee, D.-H.; Kim, H.; Choi, H.-S.; Kim, E.J.; Chung, I.-M.; Chung, I.-Y.; Yoon, D. The Liquid Panax ginseng Inhibits Epidermal Growth factor-induced metalloproteinase 9 and cyclooxygenase 2 expressions via inhibition of inhibitor factor kappa-B-alpha and extracellular signal-regulated kinase in NCI-H292 human airway epithelial cells. Am. J. Rhinol. Allergy 2011, 25, e55-e59. [CrossRef]

68. Kim, H.; Park, C.W.; Cho, S.H. The Beneficial Effect of Korean Red Ginseng Extract on Atopic Dermatitis Patients: An 8 Weeks Open, Noncomparative Clinical Study. Ann. Dermatol. 2018, 30, 304-308. [CrossRef]

69. Jung, J.H.; Kang, T.K.; Oh, J.H.; Jeong, J.U.; Ko, K.P.; Kim, S.T. The Effect of Korean Red Ginseng on Symptoms and Inflammation in Patients With Allergic Rhinitis. Ear Nose Throat J. 2020, 145561320907172. [CrossRef]

70. Park, K.-S.; Park, K.-I.; Kim, J.-W.; Yun, Y.-J.; Kim, S.-H.; Lee, C.-H.; Park, J.-W.; Lee, J.-M. Efficacy and safety of Korean red ginseng for cold hypersensitivity in the hands and feet: A randomized, double-blind, placebo-controlled trial. J. Ethnopharmacol. 2014, 158, 25-32. [CrossRef]

71. Jung, J.-W.; Kang, H.-R.; Ji, G.-E.; Park, M.-S.; Song, W.-J.; Kim, M.-H.; Kwon, J.-W.; Kim, T.-W.; Park, H.-W.; Cho, S.-H.; et al. Therapeutic Effects of Fermented Red Ginseng in Allergic Rhinitis: A Randomized, Double-Blind, Placebo-Controlled Study. Allergy, Asthma Immunol. Res. 2011, 3, 103-110. [CrossRef] [PubMed]

72. Koda, A.; Nishiyori, T.; Nagai, H.; Matsuura, N.; Tsuchiya, H. Anti-allergic actions of traditional oriental medicine-actions against types I and IV hypersensitivity reactions. Folia Pharmacol. Jpn. 1982, 80, 31-41. [CrossRef]

73. Kobayashi, H.; Mizuno, N.; Teramae, H.; Kutsuna, H.; Ueoku, S.; Onoyama, J.; Yamanaka, K.; Fujita, N.; Ishii, M. Diet and Japanese herbal medicine for recalcitrant atopic dermatitis: Efficacy and safety. Drugs Exp. Clin. Res. 2004, 30, 197-202.

74. Chen, T.; Xiao, L.; Zhu, L.; Ma, S.; Yan, T.; Ji, H. Anti-Asthmatic Effects of Ginsenoside Rb1 in a Mouse Model of Allergic Asthma Through Relegating Th1/Th2. Inflammation 2015, 38, 1814-1822. [CrossRef]

75. Han, Y.; Rhew, K.Y. Ginsenoside Rd induces protective anti-Candida albicans antibody through immunological adjuvant activity. Int. Immunopharmacol. 2013, 17, 651-657. [CrossRef]

76. Wang, L.; Zhang, F.; Cao, Z.-Y.; Xiao, Y.; Li, S.; Yu, B.; Qi, J. Ginsenoside F2 induces the release of mediators associated with Anaphylactoid reactions. Fitoterapia 2017, 121, 223-228. [CrossRef]

77. Oh, H.-A.; Seo, J.-Y.; Jeong, H.-J.; Kim, H.-M. Ginsenoside Rg1 inhibits the TSLP production in allergic rhinitis mice. Immunopharmacol. Immunotoxicol. 2013, 35, 678-686. [CrossRef]

78. Sun, J.; Song, X.; Hu, S. Ginsenoside Rg1 and Aluminum Hydroxide Synergistically Promote Immune Responses to Ovalbumin in BALB/c Mice. Clin. Vaccine Immunol. 2007, 15, 303-307. [CrossRef]

79. Lee, I.-S.; Uh, I.; Kim, K.-S.; Kim, K.-H.; Park, J.; Kim, Y.; Jung, J.-H.; Jung, H.-J.; Jang, H.-J. Anti-Inflammatory Effects of Ginsenoside Rg3 via NF-кB Pathway in A549 Cells and Human Asthmatic Lung Tissue. J. Immunol. Res. 2016, 2016, 1-11. [CrossRef]

80. Li, L.C.; Piao, H.M.; Zheng, M.Y.; Lin, Z.H.; Choi, Y.H.; Yan, G.H. Ginsenoside Rh2 attenuates allergic airway inflammation by modulating nuclear factor-?B activation in a murine model of asthma. Mol. Med. Rep. 2015, 12, 6946-6954. [CrossRef]

81. Park, E.-K.; Choo, M.-K.; Kim, E.-J.; Han, M.J.; Kim, D.-H. Antiallergic activity of ginsenoside Rh2. Boil. Pharm. Bull. 2003, 26, 1581-1584. [CrossRef] [PubMed] 
82. Bae, E.-A.; Han, M.J.; Shin, Y.-W.; Kim, N.-H. Inhibitory effects of Korean red ginseng and its genuine constituents ginsenosides $\mathrm{Rg} 3, \mathrm{Rf}$, and $\mathrm{Rh} 2$ in mouse passive cutaneous anaphylaxis reaction and contact dermatitis models. Boil. Pharm. Bull. 2006, 29, 1862-1867. [CrossRef] [PubMed]

83. Zheng, H.; Jeong, Y.; Song, J.; Ji, G.E. Oral administration of ginsenoside Rh1 inhibits the development of atopic dermatitis-like skin lesions induced by oxazolone in hairless mice. Int. Immunopharmacol. 2011, 11, 511-518. [CrossRef] [PubMed]

84. Park, E.-K.; Shin, Y.-W.; Lee, H.-U.; Kim, S.-S.; Lee, Y.-C.; Lee, B.-Y.; Kim, N.-H. Inhibitory effect of ginsenoside $\mathrm{Rb} 1$ and compound $\mathrm{K}$ on $\mathrm{NO}$ and prostaglandin $\mathrm{E} 2$ biosyntheses of RAW264.7 cells induced by lipopolysaccharide. Boil. Pharm. Bull. 2005, 28, 652-656. [CrossRef]

85. Lin, T.-J.; Wu, C.-Y.; Tsai, P.-Y.; Hsu, W.-H.; Hua, K.-F.; Chu, C.-L.; Lee, Y.-C.; Chen, A.; Lee, S.-L.; Lin, Y.-J.; et al. Accelerated and Severe Lupus Nephritis Benefits From M1, an Active Metabolite of Ginsenoside, by Regulating NLRP3 Inflammasome and T Cell Functions in Mice. Front. Immunol. 2019, 10, 1951. [CrossRef] [PubMed]

86. Ren, S.; Liu, R.; Wang, Y.; Ding, N.; Li, Y. Synthesis and biological evaluation of Ginsenoside Compound K analogues as a novel class of anti-asthmatic agents. Bioorganic Med. Chem. Lett. 2019, 29, 51-55. [CrossRef] [PubMed]

87. Shin, Y.-W.; Kim, D.-H. Antipruritic effect of ginsenoside rb1 and compound $\mathrm{k}$ in scratching behavior mouse models. J. Pharmacol. Sci. 2005, 99, 83-88. [CrossRef]

88. Kim, J.R.; Choi, J.; Kim, J.; Kim, H.; Kang, H.; Kim, E.H.; Chang, J.-H.; Kim, Y.-E.; Choi, Y.J.; Lee, K.; et al. 20-O- $\beta$-d-glucopyranosyl-20(S)-protopanaxadiol-fortified ginseng extract attenuates the development of atopic dermatitis-like symptoms in NC/Nga mice. J. Ethnopharmacol. 2014, 151, 365-371. [CrossRef]

89. Jie, Z.; Chun-Yan, L.; Jing-Ping, L.; Ren, G.; Hui, W.; Juan, P.; Sheng-Lan, L. Immunoregulation on Mice of Low Immunity and Effects on Five Kinds of Human Cancer Cells of Panax japonicus Polysaccharide. Evidence-Based Complement. Altern. Med. 2015, 2015, 839697. [CrossRef]

90. Song, J.; Han, S.-K.; Bae, K.-G.; Lim, D.-S.; Son, S.-J.; Jung, I.-S.; Yi, S.-Y.; Yun, Y.-S. Radioprotective effects of ginsan, an immunomodulator. Radiat. Res. 2003, 159, 768-774. [CrossRef]

91. Lim, Y.-J.; Na, H.-S.; Yun, Y.-S.; Choi, I.S.; Oh, J.-S.; Rhee, J.H.; Cho, B.-H.; Lee, H.C. Suppressive Effects of Ginsan on the Development of Allergic Reaction in Murine Asthmatic Model. Int. Arch. Allergy Immunol. 2009, 150, 32-42. [CrossRef] [PubMed]

92. Jung, I.D.; Kim, H.; Park, J.W.; Lee, C.-M.; Noh, K.-T.; Kang, H.-K.; Heo, D.-R.; Lee, S.-J.; Son, K.-H.; Park, H.-J.; et al. RG-II from Panax ginseng C.A. Meyer suppresses asthmatic reaction. BMB Rep. 2012, 45, 79-84. [CrossRef] [PubMed]

93. Ebeling, C.; Wu, Y.; Skappak, C.; Gordon, J.; Ilarraza, R.; Adamko, D. Compound CVT-E002 attenuates allergen-induced airway inflammation and airway hyperresponsiveness, in vivo. Mol. Nutr. Food Res. 2011, 55, 1905-1908. [CrossRef] [PubMed]

94. Lee, J.-Y.; Jin, H.J.; Park, J.-W.; Jung, S.K.; Jang, J.-Y.; Park, H.-S. A Case of Korean Ginseng-Induced Anaphylaxis Confirmed by Open Oral Challenge and Basophil Activation Test. Allergy Asthma Immunol. Res. 2011, 4, 110-111. [CrossRef] [PubMed]

95. Hon, K.L.; Leung, T.F. Neonatal urticaria due to American ginseng or not? Clin. Exp. Dermatol. 2010, 35, 103-104. [PubMed]

96. Erdle, S.C.; Chan, E.S.; Yang, H.; Vallance, B.A.; Mill, C.; Wong, T. First-reported pediatric cases of American ginseng anaphylaxis and allergy. Allergy, Asthma Clin. Immunol. 2018, 14, 79. [CrossRef]

97. Jang, S.-E.; Jung, I.-H.; Joh, E.-H.; Han, M.J.; Kim, D.-H. Antibiotics attenuate anti-scratching behavioral effect of ginsenoside Re in mice. J. Ethnopharmacol. 2012, 142, 105-112. [CrossRef]

98. Joh, E.-H.; Lee, I.-A.; Jung, I.-H.; Kim, D.-H. Ginsenoside Rb1 and its metabolite compound K inhibit IRAK-1 activation-The key step of inflammation. Biochem. Pharmacol. 2011, 82, 278-286. [CrossRef]

(C) 2020 by the authors. Licensee MDPI, Basel, Switzerland. This article is an open access article distributed under the terms and conditions of the Creative Commons Attribution (CC BY) license (http://creativecommons.org/licenses/by/4.0/). 